\title{
Short Communication: Predominance of $\beta$-Casein (CSN2) $C$ Allele in Goat Breeds Reared in Italy
}

\author{
S. Chessa, ${ }^{1}$ E. Budelli, ${ }^{2}$ F. Chiatti, ${ }^{1}$ A. M. Cito, ${ }^{3}$ P. Bolla, ${ }^{1}$ and A. Caroli ${ }^{3}$ \\ ${ }^{1}$ Dipartimento di Scienze e Tecnologie Veterinarie per la Sicurezza Alimentare, \\ Università degli Studi di Milano, 20134 Milano, Italy \\ ${ }^{2}$ Fondazione Parco Tecnologico Padano, Centro Ricerche e Studi Agroalimentari, \\ 20090 Segrate (Milano), Italy \\ ${ }^{3}$ Dipartimento di Sanità e Benessere Animale, Università di Bari, \\ 70010 Valenzano (Bari), Italy
}

\section{ABSTRACT}

A protocol for the rapid and simultaneous genotyping of $A, C$, and $O^{\prime}$ CSN2 alleles in goat was developed by single strand conformational polymorphism polymerase chain reaction (SSCP-PCR) technique. Screening the CSN2 variability in 7 goat breeds reared in Italy validated the genotyping test. The SSCP-PCR technique was also suitable for monitoring CSN2 polymorphism. In particular, the discrimination between $\mathrm{CSN} 2 * A$ and $\mathrm{CSN} 2 * C$ is important because the 2 corresponding protein variants cannot be separated by standard typing techniques. The monitoring of CSN2 variability in the goat breeds indicates the predominance of the $C$ allele. In most breeds, CSN $2 * C$ occurred with the highest frequency, except in Saanen where $\mathrm{CSN} 2 * A$ and $\mathrm{CSN} 2 * C$ showed similar frequencies. Variant CSN2 $* C$ occurred with a frequency of 0.68 (Camosciata), 0.70 (Jonica), 0.71 (Garganica), 0.82 (Maltese), 0.87 (Cilentana), and 0.97 (Orobica). The alignment among the mature CSN2 sequences of different species suggests that $\mathrm{CSN} 2 * A$ is the ancestral allele compared with $\mathrm{CSN} 2 * C$. Interestingly, the $\mathrm{CSN} 2 * A$ goat variant showed higher frequencies in selected breeds (Saanen and Camosciata).

(Key words: goat, $\beta$-casein, genetic polymorphism, single strand conformational polymorphism)

Abbreviation key: CSN2 = $\beta$-casein, IEF = isoelectrofocusing, SSCP = single strand conformational polymorphism.

Genetic polymorphism of milk proteins has been intensively studied in goat because of the deep relationships with functional and biological properties affecting milk quality, composition, and technological character-

\footnotetext{
Received October 19, 2004.

Accepted December 20, 2004.

Corresponding author: Anna Caroli; e-mail: am.caroli@ veterinaria.uniba.it.
}

istics (Martin 1993; Grosclaude et al., 1994). Goat caseins show a complex qualitative and quantitative variability, characterized by several genetic polymorphisms as well as by multiple post-translation modifications. Different transcriptional and post-transcriptional mechanisms control casein gene expression, dramatically affecting the technological properties of milk (Martin et al., 2002).

Casein genes are organized as a cluster including in the order $\alpha_{\mathrm{s} 1}$-casein, $\beta$-casein (CSN2), $\alpha_{\mathrm{s} 2}$-casein, and $\kappa$-casein loci (Ferretti et al., 1990; Threadgill and Womack, 1990). Within the cluster, the first 2 casein loci are only $12 \mathrm{~kb}$ apart and convergently transcribed (Leroux and Martin, 1996). In goats, the entire casein gene cluster region spans about $250 \mathrm{~kb}$ on chromosome 6 (Hayes et al., 1993; Popescu et al., 1996).

As far as CSN2 is concerned, 3 protein variants were found to be associated with a normal $\beta$-casein content: $\mathrm{A}, \mathrm{B}$, and $\mathrm{C}$. The $\mathrm{B}$ variant was detected by isoelectrofocusing (IEF), resulting in some bands markedly closer to the gel cathodic position than in the A variant (Mahé and Grosclaude, 1993). Genetic control of the B allele was supported by the segregation analysis in one available family. However, the variant was not further characterized. The $\mathrm{C}$ variant was identified by peptide mass fingerprinting and tandem mass spectrophotometry (Neveu et al., 2002). This variant differs from the A in the mono amino acid substitution $\mathrm{Ala}_{177}$ to $\mathrm{Val}_{177}$ of the mature protein. Because both amino acids are neutral, the mutation is not detectable by screening protein techniques such as milk IEF. At the DNA level, the protein polymorphism is justified by a nucleotide substitution GCA $\left(\mathrm{Ala}_{177}\right) \rightarrow$ GTA $\left(\mathrm{Val}_{177}\right)$, as can be observed by alignment of the sequence GenBank accession number AF409096 (Wang et al., 2001; direct submission) with AH001195 sequence (Roberts et al., 1992).

Furthermore, 2 different null CSN2 alleles were identified, both characterized by mutations responsible for premature stop codons in exon 7 , one in southern Italian breeds (Ramunno et al., 1995; GenBank accession number AJ011019) and the other in the Creole and Py- 
renean goat (Persuy et al., 1999; GenBank accession number AF172260). The mRNA analysis revealed that the transcript product amounts were almost 10 (Ramunno et al., 1995) and 100 (Persuy et al., 1999) times lower for the null alleles than for the A variant. As far as the nomenclature is concerned, the 2 null alleles were differentiated respectively by $0(\mathrm{AF} 172260)$ and $0^{\prime}$ (AJ172260) by Neveu et al. (2002). This nomenclature will be used in the present communication.

To obtain further information on goat CSN2 variability, exon 7 was analyzed by single strand conformational polymorphism- (SSCP-) PCR in 7 Italian goat breeds. An SSCP-PCR protocol was developed for typing CSN2* $0^{\prime}$ as an alternative to allele-specific PCR (Ramunno et al., 1995). Different SSCP patterns were detected and sequenced. Moreover, milk samples were typed by IEF to check the correspondence between the DNA variation and the phenotypic expression.

Blood and individual milk samples were randomly collected from 4 Southern Italian goat breeds (Garganica, Jonica, Cilentana, and Maltese), 1 Northern Italian breed (Orobica), and 2 composite breeds (Camosciata and Saanen). Four hundred seventy-three samples were analyzed. Reference samples for the $\mathrm{CSN} 2 * 0^{\prime}$ allele (GenBank accession number AJ011019) were also used. A commercial kit (GFXTM Genomic Blood DNA Purification kit, Amersham Biosciences, Piscataway, NJ) was used for DNA extraction from blood or milk.

A 374-bp fragment containing exon 7 of the goat CSN2 gene was amplified by PCR performed in a 25$\mu \mathrm{L}$ reaction mixture containing $2 \mu \mathrm{L}$ of DNA solution (100 to $150 \mathrm{ng}$ ), $10 \mathrm{pmol}$ of each primer, and $1 \times$ PCR Master Mix (Fermentas, Vilnius, Lithuania). Primers were 5'CCC AAA GTG AAG GAG ACT ATG 3', and 5' CAT CAG AAG TTA AAC AGC ACA G 3 '. The following conditions were used: an initial denaturation step of $95^{\circ} \mathrm{C}$ for $2 \mathrm{~min}$, followed by 30 cycles of $94^{\circ} \mathrm{C}$ for $45 \mathrm{~s}$, $58^{\circ} \mathrm{C}$ for $45 \mathrm{~s}, 72^{\circ} \mathrm{C}$ for $2 \mathrm{~min}$, and a final extension step of $72^{\circ} \mathrm{C}$ for 5 min using a PTC-0200 DNA Engine thermal cycler (MJ Research Inc., Waltham, MA).

For SSCP, $6 \mu \mathrm{L}$ of PCR product was added to $8 \mu \mathrm{L}$ of denaturation solution $(0.05 \%$ of xylene-cyanol, $0.05 \%$ of bromophenol blue, $0.02 M$ EDTA in deionized formamide). After heat denaturation at $95^{\circ} \mathrm{C}$ for $8 \mathrm{~min}$, the samples were immediately chilled on ice and then run overnight $(16 \mathrm{~h})$ on $10 \%$ acrylamide:bisacrylamide gels (29:1) with $1.5 \%$ glycerol in $0.5 \times$ Tris-borate-EDTA buffer at $280 \mathrm{~V}$ and $12^{\circ} \mathrm{C}$ (Penguin Dual Gel WaterCooled Electrophoresis System, OWL Scientific Inc., Woburn, MA). Bands were visualized by silver staining (Bassam et al., 1991).

The DNA samples showing different patterns on SSCP gels were randomly selected for sequencing. Eight samples were sequenced. Primers used for se-

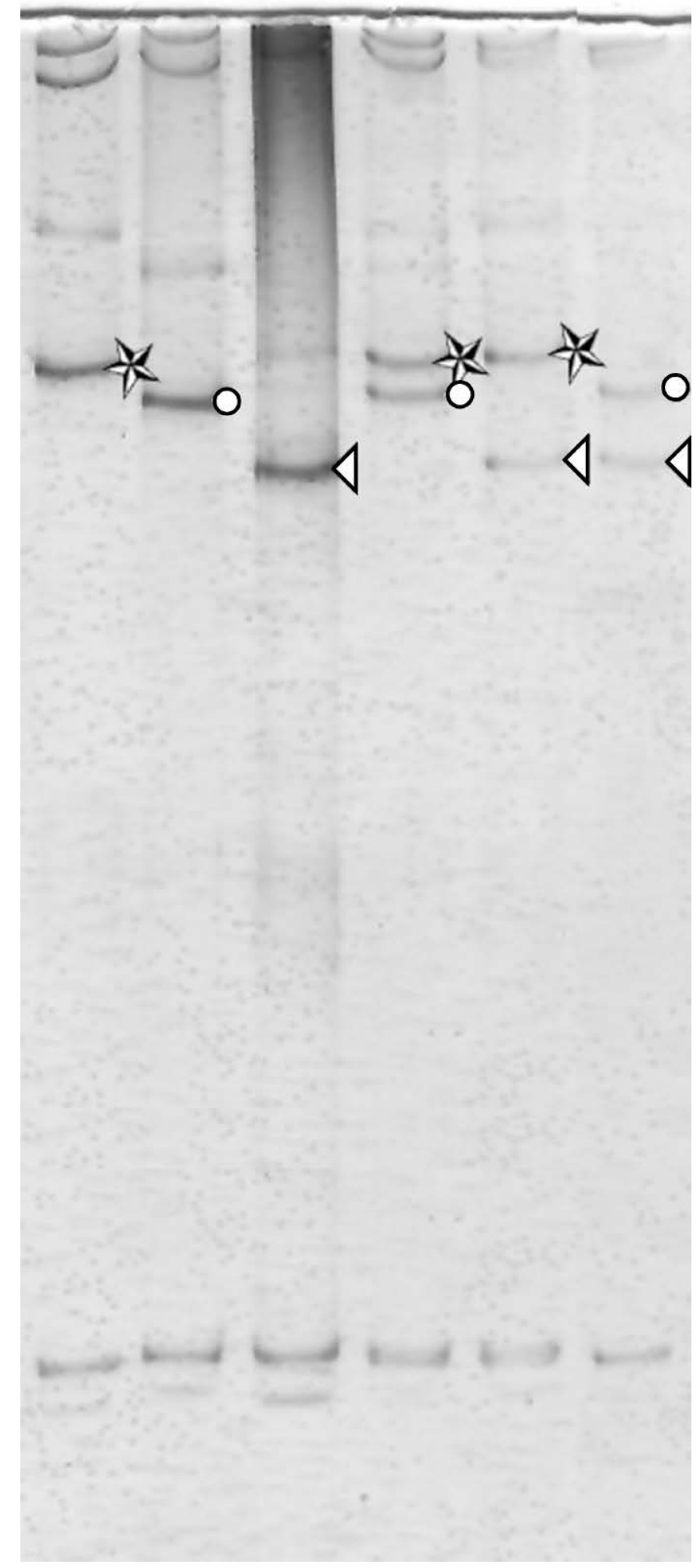

Figure 1. Single strand conformational polymorphism-PCR typing for the simultaneous detection of $\mathrm{CSN} 2 * A, \operatorname{CSN} 2 * C$, and CSN $2^{*} 0^{\prime}$ (GenBank Accession number AJ011019). Genotypes are indicated for each sample. The discriminant band for each allele is also shown (star: $\mathrm{CSN} 2 * C$, circle: $\mathrm{CSN} 2 * A$; triangle: $\mathrm{CSN} 2 * 0^{\prime}$ ). 
Table 1. Number of individuals typed (n) and allele frequencies at CSN2 locus in the different breeds. Frequencies are shown in ascending order for CSN $2 * C$.

\begin{tabular}{lrlll}
\hline & & \multicolumn{3}{c}{ CSN2 allele } \\
\cline { 3 - 5 } Breed & $\mathrm{n}$ & $A$ & $C$ & $0^{\prime}$ \\
\hline Saanen & 76 & 0.507 & 0.493 & $\ldots$ \\
Camosciata & 112 & 0.317 & 0.683 & $\ldots$ \\
Jonica & 70 & 0.207 & 0.700 & 0.093 \\
Garganica & 33 & 0.242 & 0.712 & 0.046 \\
Maltese & 58 & 0.129 & 0.819 & 0.052 \\
Cilentana & 43 & 0.035 & 0.872 & 0.093 \\
Orobica & 81 & 0.025 & 0.975 & $\ldots$ \\
\hline
\end{tabular}

quencing were the same as those used for the PCRSSCP techniques. The PCR products were sequenced by PRIMM Srl, Milano, Italy. The nucleotide sequences and the deduced amino acid sequences were analyzed with Bioedit (Hall, 1999) software.

Milk samples were typed for CSN2 by IEF according to Caroli et al. (2001).

The use of the PCR-SSCP method developed gave the opportunity to identify the $\mathrm{CSN} 2 * \mathrm{C}$ allele at the DNA level simultaneously with CSN $2 * A$ and $\mathrm{CSN} 2 * 0^{\prime}$ (Figure 1). Three main bands with increasing electrophoretic mobility were identified and attributed respectively to $\mathrm{CSN} 2^{*} C, A$, and $O^{\prime}$ on the basis of sequencing results or reference sample comparison, or both. The correspondence between the $\mathrm{CSN} 2 * C$ protein variant and SSCP was demonstrated by sequencing (GenBank AY563136). The nucleotide exchange $\mathrm{C} \rightarrow \mathrm{T}$ was found in all the sequenced samples presenting the CSN $2 * C$ band ( $2 \mathrm{AC}, 1 \mathrm{CO}^{\prime}, 2 \mathrm{CC}$ ), whereas it did not occur in the other $3 \mathrm{DNA}$ samples sequenced $\left(2 A A, 1 A 0^{\prime}\right)$.

Thus, the PCR-SSCP technique is particularly suitable for the study of CSN2 variability. The discrimination between the $A$ and $C$ variants is important because the 2 variants are not identifiable at the protein level by standard typing methods, as shown by IEF. This technique allows separating 2 major and 2 minor bands of CSN2, simultaneously with alleles at other casein loci (Caroli et al., 2001; Erhardt et al., 2002). The occurrence of the $\mathrm{B}$ variant was excluded by comparing our results with the literature (Mahé and Grosclaude, 1993). Moreover, the comigration of $A$ and $C$ variants at the protein level was confirmed by IEF, and the presence of new phenotypes in the typed breeds was excluded.

The monitoring of CSN2 variability in goat breeds reared in Italy clearly indicates the predominance of $\mathrm{CSN} 2 * C$. Except for Saanen, where CSN2*A and $\mathrm{CSN} 2 * C$ showed similar frequencies, $\mathrm{CSN} 2 * C$ occurred with a higher frequency than $\mathrm{CSN} 2 * A$. Frequencies of CSN2 ${ }^{*}$ were 0.68 (Camosciata), 0.70 (Jonica), 0.71 (Garganica), 0.82 (Maltese), 0.87 (Cilentana), and 0.97 (Orobica) (Table 1 ). The $\mathrm{CSN} 2 * 0^{\prime}$ allele was found only in the Italian southern breeds, at frequencies ranging from 0.046 (Garganica) to 0.093 (Cilentana and Jonica). No individual homozygous for $\mathrm{CSN} 2 * 0^{\prime}$ allele was observed, as expected on the basis of Hardy-Weinberg equilibrium, which was verified in all breeds. No search was performed for the null allele CSN2*0 identified in Creole and Pyrenean goat (Persuy et al., 1999), and, in the future, it would be useful to include this variant in the PCR-SSCP typing test for goat CSN2.

From a phylogenetic point of view, the alignment among the mature CSN2 sequences of different species (Figure 2) suggests that CSN2*A is the ancestral allele compared with $\mathrm{CSN} 2 * C$. In the figure, protein sequences (http://www.ebi.ac.uk/swissprot/) are shown starting from the amino acid position 158 of caprine CSN2. Sequences 1 and 2 are deduced, respectively, from goat CSN2*A (Roberts et al., 1992) and CSN2*C (Wang et al. 2001, direct submission) alleles. In the other ruminants (sequence $3=$ sheep; 4 = bovine; $5=$ buffalo), alanine occurs in the position corresponding to goat amino acid 177, thus suggesting a more ancestral origin of goat CSN $2 * A$ if compared with $\mathrm{CSN} 2 * C$. However, valine occurs at the 177 th correspondent position in sequences 6 (pig), 7 (human), and 8 (rabbit), which, as expected, exhibit a higher divergence from caprine

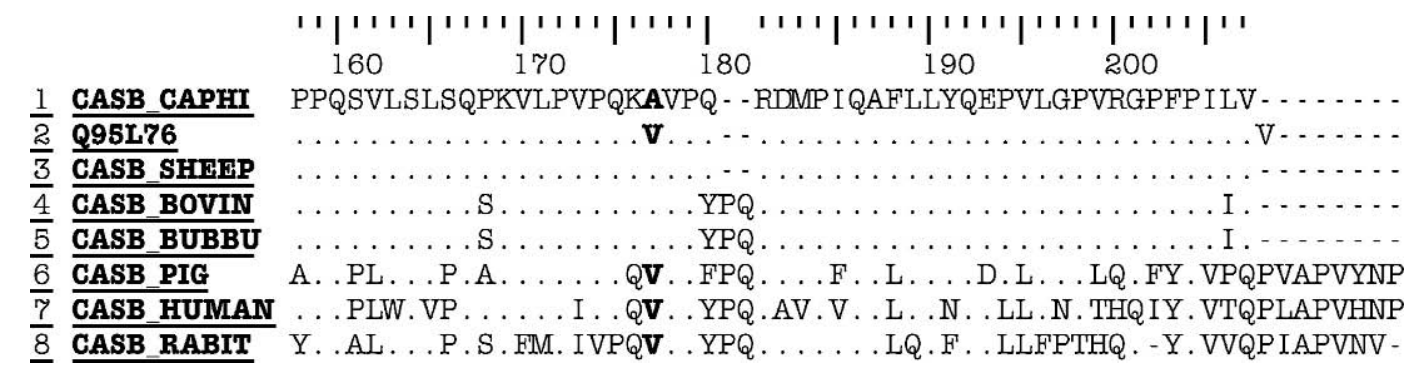

Figure 2. Alignment of the mature CSN2 of different species, starting from the amino acid position 158 of the caprine CSN2, to which the headline refers. Sequences 1 and 2 are deduced, respectively, from CSN2*A (Roberts et al., 1992) and CSN2*C (Wang et al., 2001; direct submission) goat variants. Web site: http://www.ebi.ac.uk/swissprot/. 
CSN2 than ruminants. In all cases, the fact that $\mathrm{CSN} 2 * A$ goat variant shows higher frequencies in selected breeds (Saanen and Camosciata) than in isolated populations should be further investigated in the light of functional and adaptive aspects, and taking into account the genetic polymorphism at the other casein genes.

Comparison with literature data on goat CSN2 allele frequencies is difficult due to the low level of polymorphism detected at this locus until now. No indication is given about the incidence of the $\mathrm{C}$ allele in the different breeds by the authors who identified this variant (Neveu et al., 2002). The $O^{\prime}$ allele was found in a local southern Italian population with a frequency of 0.1 (Rando et al., 1996). The 0 allele was found in a large flock of Creole goats (Mahé and Grosclaude, 1993) and in thousands of animals of the Pyrenean breed (Persuy et al., 1999) with a frequency of 0.2 and 0.12 , respectively.

In conclusion, $\mathrm{CSN} 2 * C$ is the predominant allele in goat breeds reared in Italy. The SSCP-PCR test developed is a rapid method to screen goat breeds at the CSN2 locus. The demonstrated polymorphism should be considered in addition to the already known variants at the other casein loci, to include casein haplotype information in breeding programs for the genetic improvement of domestic goats.

\section{ACKNOWLEDGMENTS}

The DNA reference samples carrying the $\mathrm{CSN} 2 * 0^{\prime}$ allele were a kind gift from Luigi Ramunno and coworkers. The research was partially supported by MURST contract year 2002 - prot. 2002072131.

\section{REFERENCES}

Bassam, B. J., G. Caetano-Anolles, and P. M. Gresshoff. 1991. Fast and sensitive silver staining of DNA in polyacrylamide gels. Anal. Biochem. 196:80-83.

Caroli, A., O. Jann, E. Budelli, P. Bolla, S. Jäger, and G. Erhardt. 2001. Genetic polymorphism of goat $\kappa$-casein (CSN3) in different breeds and characterization at DNA level. Anim. Genet. $32: 226-230$.
Erhardt, G., S. Jäger, E. Budelli, and A. Caroli. 2002. Genetic polymorphism of goat $\alpha_{\mathrm{S} 2}$-casein (CSN1S2) and evidence for a further allele. Milchwissenschaft 57:137-140.

Ferretti, L., P. Leone, and V. Sgaramella. 1990. Long-range restriction analysis of the bovine casein genes. Nucleic Acids Res. 18:6829-6833.

Grosclaude, F., G. Ricordeau, P. Martin, F. Remeuf, L. Vassal, and J. Bouillon. 1994. Du géne au fromage: Le polymorphisme de la caséine $\alpha$ s1 caprine, ses effets, son évolution. INRA Prod. Anim. $7: 3-19$.

Hall, T. A. 1999. BioEdit: A user-friendly biological sequence alignment editor and analysis program for Windows 95/98/NT. Nucl. Acids. Symp. Ser. 41:95-98.

Hayes, H., E. Petit, C. Bouniol, and P. Popescu. 1993. Localisation of the alpha-S2-casein gene (CASAS2) to the homologous cattle, sheep and goat chromosome 4 by in situ hybridisation. Cytogenet. Cell Genet. 64:282-285.

Leroux, C., and P. Martin. 1996. The caprine alpha $\mathrm{S}^{-}$and betacaseins genes are $12 \mathrm{~kb}$ apart and convergently transcribed. Anim. Genet. 27(Suppl. 2):293.

Mahé, M. F., and F. Grosclaude. 1993. Polymorphism of $\beta$-casein in the Creole goat of Guadeloupe, evidence for a null allele. Genet. Sel. Evol. 25:403-408.

Martin, P. 1993. Polymorphisme génétique des lactoprotéines caprines. Lait 73:511-532.

Martin, P., M. Szymanowska, L. Zwierzchowski, and C. Leroux. 2002 The impact of genetic polymorphisms on the protein composition of ruminants' milks. Reprod. Nutr. Dev. 42:433-459.

Neveu, C., D. Mollé, J. Moreno, P. Martin, and J. Léonid. 2002. Heterogeneity of caprine beta-casein elucidated by RP-HPLC/MS Genetic variants and phosphorylation. J. Protein Chem. 21:557-567.

Persuy, M. A., C. Printz, J. F. Medrano, and J. C. Mercier. 1999. A single nucleotide deletion resulting in a premature stop codon is associated with marked reduction of transcripts from a goat $\beta$ casein null allele. Anim. Genet. 30:444-451.

Popescu, C. P., S. Long, P. Riggs, J. Womack, S. Schmutz, R. Fries, and D. S. Gallagher. 1996. Standardization of cattle karyotype nomenclature: Report of the committee for the standardization of the cattle karyotype. Cytogenet. Cell Genet. 74:259-261.

Ramunno, L., P. Mariani, M. Pappalardo, A. Rando, M. Capuano, P. Di Gregorio, and G. Cosenza. 1995. Un gene ad effetto maggiore sul contenuto di caseina $\beta$ nel latte di capra. XI Conv. ASPA, 185186, Grado (GO), DISPA, Udine, Italy.

Rando, A., M. Pappalardo, M. Capuano, P. Di Gregorio, and L. Ramunno. 1996. Two mutations might be responsible for the absence of $\beta$-casein in goat milk. Anim. Genet. 27:31.

Roberts, B., P. DiTullio, J. Vitale, K. Hehir, and K. Gordon. 1992. Cloning of the goat beta-casein-encoding gene and expression in transgenic mice. Gene 121:255-262.

Threadgill, D. W., and J. E. Womack. 1990. Genomic analysis of the major bovine milk protein genes. Nucleic Acids Res. 18:69356942.

Wang, Q., Z. Huang, M. J. Chen, S. Z. Huang, and Y. T. Zeng. 2001. GenBank Accession no. AF409096 [Capra hircus $\beta$-casein precursor (csn2) gene, complete cds]. Online. Available: http:// www.ncbi.nml.nih.gov/. Accessed Feb. 21, 2005. 